\title{
Protecting Colombian Refugees in the Andean Region: The Fight against Invisibility ${ }^{*}$
}

Martin Gottwald

En la última década, el desplazamiento forzado de personas se incrementó en Colombia como resultado de las violaciones al Derecho Internacional Humanitario y a los Derechos Humanos. Con anterioridad a la celebración del 20 aniversario de la Declaración de Cartagena sobre refugiados, la mayoría de países vecinos se esforzaron por evitar que el conflicto en Colombia se volviese internacional, negando el efecto transfronterizo del mismo y adoptando medidas para proteger sus territorios. Esta estrategia, sin embargo, fue inadecuada ya que los grupos irregulares colombianos expandieron sus operaciones en territorios vecinos y el número de refugiados se incrementó. El ACNUR se percató que el conflicto en Colombia no sólo producía desplazados internos y empezó a realizar estudios en la zona y a establecer un sistema de registro como actos encaminados a facilitar el futuro establecimiento de un régimen especial de protección de refugiados en la región andina. 


\section{Protecting Colombian Refugees in the Andean Region: The Fight against Invisibility ${ }^{*}$}

\section{Martin Gottwald}

\section{Introduction}

In his book The Pursuit of Unhappiness, ${ }^{1}$ Paul Watzlawick tells the story of Nasruddin, the Sufi sage, who was crawling around the campfire in front of his desert tent when a friend walked by:

- «What are you looking for?»

- «My key» At this his friend got on his knees and joined in the search, soon another friend came by and there were three of them helping, then a fourth. Soon, a fifth friend came by and asked, "What are you looking for?»

- «M key»

- El presente artículo ha sido publicado previamente en International Journal of Refugee Law, vol. 16 n. ${ }^{\circ}$, Oxford University Press, 2004. Para efectos de su aparición en Agenda Internacional, se cuenta con la debida autorización del autor y de los editores de la antes mencionada publicación.

1 Watzlawick, Paul. The Situation Is Hopeless, but not Serious (The Pursuit of Unhappiness), 1982. 
—

— «In my tent? Then why are all of you looking for it out here?»

— «Because the light is better here.»

What this trivial joke shows is that while constructing a subjective reality based on personal interests, rules are bound to emerge. When the U.S. Committee for Refugees published the paper 'Colombia's Silent Crisis: One Million Displaced by Violence'2 in 1998 it focused on international displacement and the scant attention it has attracted internationally. Since then, Colombia's conflict has significantly widened and worsened, causing not only internal displacement but also ever growing refugee outflows to neighboring countries in the Andean region and beyond. Strong political and security interests of key actors striving to prevent the conflict and the protection of its victims from becoming international have meant that the external displacement of tens of thousands of Colombians since the end of the 1990s has remained invisible.

The purpose of the present paper is to shed light on the hitherto virtually unknown plight of refugees in Colombia's neighboring countries and the unwillingness of most governments to acknowledge the problem and grant international protection. The document will first explain how in Colombia in the 1990s ever stronger armed non-state actors gradually expanded throughout the entire territory and started directly targeting the civilian population, particularly in border departments, thus triggering large refugee movements into neighboring countries' territories.

The paper will then describe how the foreign policy and security interests of Colombia, its neighboring countries and other key actors led to the emergence of informal rules and deterrent measures which have prevented refugee streams from becoming visible and obtaining international protection. These measures have conflicted with international refugee law, human rights law and regional protection standards such as the 1984 Cartagena Declaration on Refugees.

The document will thereafter highlight how refugees struggle in neighboring countries with pressing security and humanitarian needs as a result of their invisible and irregular status. Finally, the paper will stress how UNHCR and NGOs have thus far striven to cope with the challenge of protecting invisible refugees. It will set out strategies to make the existence and plight of the refugees visible and to meet their pressing protection needs. The article suggests that the $20^{\text {th }}$ anniversary of the 1984 Declaration is an excellent opportunity to revitalize the Declaration and adopt, based on the Declaration's extended refugee definition, a regional protection regime for Colombian refugees.

2 U.S. Committee for Refugees, «Colombia's Silent Crisis: One Million Displaced by Violence (Issue Paper)», 1998, <http://www.refugees.org/world/countryindex/colombia.cfm>. 
While Brazil, Peru, Ecuador, Panama and Venezuela share a $6000 \mathrm{~km}$ border with Colombia, the impact of the Colombian conflict on them and their governments' response to spill-over effects have differed. Whereas Colombia's most violent departments are at the borders with Ecuador, Panama and Venezuela, by contrast Brazil and Peru neighbour scarcely populated jungle areas and are thus less exposed to refugee movements. The paper will therefore mainly focus on the former asylumcountries and contrast the restrictive policies of Venezuela and Panama with the humanitarian stance of Ecuador.

\section{Background}

\subsection{The Evolution of Colombia's Conflict}

The history ${ }^{3}$ of Colombia's conflict has been characterized by a gradual evolution from an ideology-based conflict to a conflict driven by economic interests and territorial control. The international community has acknowledged the complexity of the conflict; any attempt to briefly summarize its evolution risks oversimplifying complex facts. ${ }^{4}$

In the "Era of Violence» (1948-1965), the two sharply divided traditional political parties (Liberals and Communists) began to organize in self-defense groups along political lines that later transformed themselves into peasant guerrilla forces launching a bloody civil war. In due course the armed forces and the police, through the employment of U.S. counter-insurgency tactics including rural militias and civic-action programmes, managed to subdue the irregular groups though not to pacify the country.

The period that followed saw the rise and transformation of the insurgency. The FARC (Revolutionary Armed Forces of Colombia), founded by peasants in 1965, with the support of the Soviet Union, adhered to a communist ideology. The ELN (National Liberation Army), founded by Colombian university students in 1965 as an insurgent organization with close ties to Cuba, aimed to topple the regime, push back «U.S. imperialism» and implement far-reaching socio-economic reforms.

After the collapse of the Soviet Union in 1991, the FARC went its own way in the vast isolation of rural Colombia. Bereft of any meaningful ideological ties and financed mostly by extortion, kidnapping and 'taxes' obtained in exchange for protection of

3 This section draws on International Crisis Group (ICG), «Colombia's Elusive Quest for Peace», Latin America Report, n. ${ }^{\circ}$ 1, 26 Mar. 2002.

4 The Representative of the UN Secretary-General on internally displaced person stresses in paragraph 20 of his report dated 11 Jan. 2000 (E/CN.4/2000/83/Add.1) on his follow-up mission to Colombia that «it is important to recall the complexity of the conflict owing to the multiplicity of actors and interests involved». 
drug traffickers and thousands of small and large coca farmers, the FARC significantly expanded its ranks, consolidated its territorial control, including smaller urban centers, and enhanced its military capability. It became a national insurgency with military fronts in most parts of the country, whereas the ELN remained a regional movement in the northern departments of the country.

During the 1990s, insurgent groups shifted from traditional guerrilla tactics of dispersed and mobile forces that engaged in «hit and run», to the permanent occupation of territory by means of larger units capable of repelling attacks by government forces. This implied a significant increase in its recruitment, with the FARC reaching 17000 fighters and 10000 militia, whereas ELN combatants amount to some 3500 .

The emergence of so-called paramilitary forces in the early 1980s was closely related to the expansion of the illegal drug trade and the government's counter-insurgency efforts. In the beginning, the role of the paramilitary cadres, among them active service and retired army and police personnel, former insurgents and emerald miners, was mainly to protect large landowners and drug barons form guerrilla extortion, kidnapping and assassinations. The paramilitaries were partially organized and armed by the Colombian military and participated in campaigns of the regular armed forces against the guerrilla groups, in the middle Magdalena Valley, north of Bogota. With traditional army operations failing against insurgency, the paramilitary groups gradually expanded their radius of operations, moving towards the department of Cordoba on the Atlantic coast and then west into Uraba and south into Meta and Putumayo. After a temporary decline in the early 1990 s, the paramilitary groups began to emancipate themselves from the army commanders, drug barons, large landowners, industrialists and bankers who had been their masters. Numbering 850 in 1992, they had grown to more than 8000 by 2001 , achieving by the end of the 1990 s a united paramilitary structure across Colombia funded mainly by its involvement with drug-traffickers.

Similarly, since 1998, the armed forces have been subject to profound administrative, organizational and strategic changes intended to enhance their performance in defense and security planning, counter-insurgency and counter-narcotics operations. While in 1998 the army's strength was 133000 soldiers of whom approximately 40000 were combat troops, in early 2002 this radio increased to $150000 / 55000$ equipped with new armaments provided by the US.

The administrations of Colombia and the US conceived in 1999 the controversial «Plan Colombia» as a comprehensive package, covering economic, fiscal and financial policy, peace, national defense, judicial and human rights, counter-narcotics, alternative development, social participation and human development. However, the Plan was widely perceived as a measure geared at improving the Colombian military's capacity to wage war not only against drugs, which provide the main source of revenue for the insurgency, but against the insurgency as well.

In February 2002, negotiations to end the most dangerous confrontation of Colombia's decades of civil war collapsed after four years of fruitless peace negotiations 
between the government and the guerrillas in the south of Colombia came to an end, raising fears of a further deterioration of the armed conflict and the humanitarian crisis.

\subsection{The Impact of the Conflict on the Civilian Population}

As the initially ideology-based conflict evolved into a conflict over the drug industry and territorial control, the humanitarian consequences of the conflict for the civil population dramatically increased. ${ }^{5}$ Until the 1990 s, the insurgency led a mainly "hit and run' guerrilla war directed against the armed forces in key areas in the interior of the country.

At this time, violations of humanitarian law and human rights of the civilian population by the army and insurgents were a by-product of the conflict rather than the primary intention of the armed actors. Already, by then, individuals with a prominent profile who feared persecution by the armed actors had difficulty in finding security anywhere in the country and had to seek international protection outside Colombia. However, the civilian population fleeing combat between the armed actors could usually still relocate to safer areas of the country where armed actors were not yet established.

In the 1990s, the insurgency gradually expanded its spheres of influence and gained territorial control over areas with significant production of coca, oil, bananas and coffee, bordering Panama (Uraba region), Ecuador (Putumayo) and Venezuela (Arauca, North Santander). Paramilitary groups soon started expanding their radius of operation to dispute territories conquered by the guerrilla groups, considering the civil population in these territories as the guerrillas' socio-economic basis and thus a military target. Territorial control has also been viewed as an effective way of «strengthening one's hand» for any possible negotiations with the Colombian government - the armed groups believing that the greater their territorial control, the stronger their opportunities for dialogue.

Civilians have thus come to be considered by the irregular groups as a military objective, with the result that the non-combatant and protected status of the civilian population has become severely degraded. Violations of humanitarian law and human rights such as extrajudicial and arbitrary executions (often in the form of massacres or collective killings) enforced disappearances, torture, hostage-taking and attacks

5 This section draws inter alia on the «Profiles in displacement: follow-up mission to Colombia». Report of the Representative of the Secretary-General on Internally Displaced Persons (E/CN.4/2000/83/Add.1), 11 Jan. 2000; «Report of the United Nations High Commissioner for Human Rights on the human rights situation in Colombia» (E/CN.4/2002/17, 28 Feb. 2002); «International protection considerations regarding Colombian asylum-seekers and refugees». UNHCR, 2002; and «Colombia: Report on Forced Displacement 1998-1999», Project Councelling Service, 1999. 
against the civilian population and civilian targets were suddenly no longer a byproduct of the conflict, but a deliberate means of counter-insurgency operations.

Equally, forced displacement has become an objective in itself. Entire areas are 'cleansed' of the support they are suspected of providing to the 'enemy' via mass displacement of whole communities. When the land concerned is of strategic value in military or economic terms, it is repopulated by supporters of the forces conducting the displacement. Frequently, these mass displacements are announced in advance, with those who fail to follow the order to move find themselves at risk of massacre or other serious attack upon their physical security. By contrast, armed confrontations between the irregular groups have been rare.

With the armed groups dramatically increasing the number of combatants, purchasing ever stronger armaments and systematically spreading their operations to the entire territory, access to safe areas for internal displacement, available until the 1990s, came to an end. Given the generalized nature of the conflict, today risk-free areas are extremely limited if they exist at all. People targeted by any armed group for individual persecution will not find effective protection and safety in any part of the country. In this way, agents of persecution have demonstrated that they have a national presence and an ability to act both in rural and urban areas. Armed actors have been able to track down IDPs anywhere in the country.

To summarize, from the mid-1990s the threat by the armed irregular groups to the civilian population throughout the entire country, particularly in the departments bordering Venezuela, Panama and Ecuador, increased to such an extent that an increasing number of group and individuals started to cross the country's international boundaries and seek international protection.

\section{The International Dimension: Interests of Key Actors Versus Compli- ance with International Refugee and Human Rights Law}

\subsection{The Regional Legal Framework for the Protection of Refugees}

All countries in the Andean region are parties to the international refugee instruments and have either signed ${ }^{6}$ the 1984 Cartagena Declaration on Refugees or incorporated its extended refugee definition into their national legislations. ${ }^{7}$ The 1984 Cartagena

6 In Nov. 1984, experts and representatives from ten governments, including Colombia, Venezuela and Panama, met in Cartagena de Indias (Colombia) and held a Colloquium on the international protection of refugees in Central America. The meeting resulted in the Cartagena Declaration on Refugees. It is noteworthy, that the Venezuela government emphasized in its reply to the Inter-American Human Rights Commission's precautionary measures in favour of a group of refugees from Colombia on Venezuelan territory that it applies the 1984 Declaration in its asylum-policy.

7 Ecuador, Peru, Brazil and Peru are among those countries in the region that incorporated subsequently the extended refugee definition of the Declaration in their national refugee legislations. 
Declaration and the 1989 International Conference on Central American Refugees (CIREFCA) have been considered as examples for pragmatic humanitarian solutions to regional refugee problems. ${ }^{8}$ The Declaration is considered the main contribution of the Americas to the international refugee protection framework.

The 1984 Cartagena Declaration on Refugees recommends that the definition of a refugee to be used in the region include, in addition to the elements of the 1951 Convention and the 1967 Protocol, persons who have fled their country because their lives, safety or freedom have been threatened by generalized violence, foreign aggression, internal conflicts, massive violation of human rights or other circumstances seriously disturbing public order. It is not a formally binding treaty, but represents endorsement by the States concerned of appropriate and applicable standards of protection and assistance. ${ }^{9}$

The Cartagena Declaration reiterates, inter alia, the commitment of governments in the region to support the work performed by UNHCR and to facilitate the fulfilment of his mandate. Furthermore, it calls upon states 'to ensure that any repatriation of refugees is voluntary, and is declared to be so on an individual basis, and is carried out with the cooperation of UNHCR'. These provisions reflect the obligation to respect and accept UNHCR's international protection activities as provided by Article 35 paragraph 1 of the 1951 Convention. In particular, UNHCR's supervisory role includes the prompt and unhindered access to asylum seekers, refugees and returnees, and to monitor their treatment. ${ }^{10}$

Colombia and its neighboring countries are also parties to various international human rights instruments. Particular reference should be made to the 1969 American Convention on Human Rights which enshrines various refugee rights. Article 22 paragraph 7 of the American Convention stipulates that every person has the right to seek and be granted asylum in a foreign territory, in accordance with the legislation of the state and international conventions. This provision encompasses not only asilados $^{11}$ but also refugees and asylum-seekers under the 1951 Convention and its

8 Arboleda, E. «Refugee Definition in Africa and Latin America: The Lessons of Pragmatism», 3 IFRL 185 (1991).

9 Goodwin-Gill, Guy S. "The Refugee in International Law (Second Edition)», 1996, 21; UNHCR suggested in its written opinion to the Inter-American Commission on Human Rights in Aug. 2001 regarding the Commission's precautionary measures against Venezuela that the Cartagena Declaration has acquired the status of regional customary Law. UNHCR referred inter alia to the fact that the OAS General Assembly has consistently endorsed the Cartagena Declaration.

10 KäLIN, Walter. «Supervising the 1951 Convention relating to the status of refugees: article 35 and beyond» In Erika Feller, Volker Türk and Frances Nicholson (eds.), Refugee Protection in International Law, 2003, p. 622.

11 Latin America has long been familiar with the concept of asilado under various treaties such as the Conventions on Territorial Asylum and Diplomatic Asylum of 28 Mar. 1954. The beneficiaries are usually described as being sought «for political reasons» or «for political offences» although the 1954 Caracas Convention expressly refers to persons coming from a 
1967 Protocol relating to the status of refugees. Moreover, the wording of Article 22 paragraph 7 suggests that international refugee law and international standards ${ }^{12}$ shall be used for its interpretation. According to UNHCR, Article 22 paragraph 7 requires states to adopt fair and efficient refugee status determination procedures such as outlined in EXCOM conclusion N. ${ }^{\circ} 8$ (XXVIII) of 1997 and various resolutions of the General Assembly.

Article 22 paragraph 8 of the American Convention on Human Rights establishes that in no case may an alien be deported or returned to a country, regardless of whether or not it is his country of origin, if in that country his right to life or personal freedom is in danger of being violated because of his race, nationality, religion, social status, or political opinions'. This provision complements the principle of nonrefoulement enshrined in Article 33 of the 1951 Convention in that it protects not only refugees but aliens in general.

Finally, Article 22 paragraph 9 of the American Convention provides that the collective expulsion of aliens is prohibited. The Inter-American Court of Human Rights has used this provision to define standards related to a due process in deportation procedures. ${ }^{13}$

State «in which they are persecuted for their beliefs, opinions, or political affiliations, or for acts which may be considered as political offences». The Regional Experts Meeting in San José (Global Consultations on International Protection) concluded in June 2001 that there is no basis for distinguishing the concepts of «refuge» (refugio) developed in the framework of the United Nations and «asylum» (asilo) such as practiced in Latin America, as they share the same underlying premise, namely the protection of persecuted individuals.

12 Article 29 paragraph d) of the American Convention on Human Rights stipulates that 'no provision of this Convention shall be interpreted as excluding or limiting the effect that the American Declaration of the Rights and Duties of Man and other international acts of the same nature may have'. The wording ('other acts') and the fact that the American Declaration is strictly speaking not a legally binding treaty suggests that not only binding international law but also international soft law such as the 1984 Cartagena Declaration on Refugees and Conclusions by the Executive Committee of the High Commissioner's Programme shall be used in the interpretation of the American Convention on Human Rights.

${ }^{13}$ Provisional Measures of the Inter-American Court on Human Rights against the Dominican Republic (18 August 2000). Case of Haitians and Dominicans of Haitian origin in the Dominican Republic, <http://heiwww.unige.ch/humanrts/iachr/E/3-esp-14.html>. In 1999, the Inter-American Commission received information denouncing the mass explosion of Haitians and Dominicans of Haitian origin from the Dominican Republic. The expulsions were allegedly carried out on a collective basis without any judicial proceedings to determine an individual's nationality, immigration status, or family connections to the Dominican Republic. The Commission requested the Dominican Republic to adopt precautionary measures to protect those individuals facing collective expulsion or deportation. As the Dominican Republic did not change its policy related to the deportations, the Commission requested in 2000 that the Inter-American Court on Human Rights order provisional measures to include the immediate return of several named individuals and their protection within the Dominican Republic from detention and deportation motivated by race or national origin. In addition, the 


\subsection{Political and Security Interests of Key Actors}

In line with the 'theory of constructivism', key actors in and around Colombia have constructed the reality of a conflict, based on their political and security interests, without international dimension.

With as much as a 75 per cent of Colombia's territory either controlled or contested by insurgent and paramilitary forces, the Colombian government's primary interest has been to identify measures to strengthen the state an regain control over its territory, while internationally striving to show its ability to cope with the conflict. As a result, the humanitarian costs of the conflict have not been duly recognized and the conflict's international dimension, including refugee outflows and operations by Colombia's irregular groups in the territories of neighboring countries, has been minimized.

The government's endeavours have been aimed at seeking international support for its counter-insurgency strategy. At the same time it has downplayed the issues of forced displacement and seeking the prompt return of refugee groups to Colombia. It should be noted however that the government has sought to alleviate the plight of Colombians in neighboring countries from a migration point of view, encouraging particularly Panama and Venezuela to accord better treatment to Colombian migrants.

Sharing a 6000 kilometre border, Colombia's neighbours' interests have been political and security related. Politically speaking, many have perceived refugee outflows as a result of the US backed Plan Colombia. This perception has been expressed in stronger terms since left leaning populists re-emerged as leaders of state in Venezuela, Brazil and Ecuador; advocating economic nationalism, railing against the freetrade, macroeconomic and counter-drug policies promoted by the US and elevating nationalism to centre stage. Keeping informal contacts with Colombia's insurgent groups, in part through the Sao Paulo Forum, a hemispheric umbrella group for Latin American Marxist and socialist parties, former guerrilla organizations and active rebel groups, these leaders have rejected the US expanding military support for Colombia considering it part of a more ambitious long-term strategy to gain direct control over oil and other natural resources in South America.

To their mind, the Bush administration is backing what they perceive as a conservative government in Colombia while increasing US military and economic presence in other Andean countries with substantial energy, mineral and forest resources. Neighboring countries' position has been that these two countries (Colombia and the US) have to contain the conflict and resulting population movements within Colombia, so that their territories are not affected. In addition, political turmoil in various Andean countries

Commission petitioned the Court to adopt provisional measures that would require the Dominican Republic to suspend all mass expulsions and to establish procedural guarantees for all individuals facing deportation (notification, access to family members and full hearing before competent authorities). 
has meant that only limited attention has been paid to the humanitarian consequences of Colombia's conflict. Unfamiliarity with international refugee law and limited institutional capacity to deal with international refugee flows has further compounded this situation.

Colombia's 6000 kilometre border is for the most part remote jungle, mountain and desert areas difficult to access and secure. This border has been the centre of largescale smuggling and lawlessness, trespassed by insurgents and government security forces, as well as drug and arms traffickers. ${ }^{14}$ Neighboring countries fear that Colombia's conflict will spill over to their territories, especially given the unstable political and economic conditions in Venezuela, Ecuador and Peru.

It is noteworthy that Colombia's guerrilla groups have established a permanent presence in virtually all the border areas of neighboring countries, for rest, supply and preparation of military operations against Colombia's army and paramilitary forces. ${ }^{15}$ Whereas the Venezuelan government has been accused of not only knowingly tolerating insurgents on its territory but also maintaining support, other neighboring countries have been simply unable to effectively protect their border areas, and thus had to tacitly allow insurgent operations in their territories, while striving to avoid international attention.

The presence of armed irregular groups from Colombia on the soil of neighboring countries has conflicted with state obligations under the UN Charter. Article 2 paragraph 4 of the UN Charter establishes that «all members shall refrain in their international relations from the threat or use of force against the territorial integrity or political independence of any state, or in any other manner inconsistent with the Purposes of the United Nations». The essential purpose and the principle enshrined in Article 2 paragraph 4 of the Charter were interpreted and elaborated by the International Court of Justice (ICJ) in a precedent setting decision on the responsibility of the United States of America for military and paramilitary activities in Nicaragua. ${ }^{16}$ The ICJ referenced General Assembly Resolution 2625 (xxv) ${ }^{17}$ to clarify the notion of the use of force. The Court pointed out that the prohibition goes beyond the direct use of classical inter-state military force and includes any use of armed force across borders, such as incursion into the territory of another state, as well as indirect armed force. Indirect armed force includes not only the provision of weapons, but also the mere «assisting», «encouraging» and even «tolerating» armed activities by irregular

14 National Geographic, «Cocaine Country: The Colombian Villages Where Coke is King», July 2004.

15 International Crisis Group. «Colombia and Its Neighbors: The Tentacles of Instability», 8 April 2003, www.crisisweb.org.

16 International Court Justice, Case Concerning Military and Paramilitary Activities in and against Nicaragua (Nicaragua v. US), [1986] I.C.J. Rep. 14, at paras. 195 and 228.

17 United Nations General Assembly. Declaration on Principles of International Law Concerning Friendly Relations and Co-operation among States in Accordance with the Charter of the United Nations, UNGA Res. 2625 (xxv) adopted on 24 Oct. 1970. 
groups. ${ }^{18}$ Failure to prevent the use of its territory for these purposes will engage the international responsibility of the host state. ${ }^{19}$

Against this background, it is hardly surprising that neighboring countries have tried to keep forced population movements off their territories and shed as little light as possible on the presence of those refugee groups that have managed to enter. Special reference has to be made to Ecuador's stance which has been characterized not only by the above political and security considerations, but also by a humanitarian tradition, commitment to international obligations and concern over its international image.

The priorities of the United States in the Andean region have been to target the narcotics industry which affects its own territory, to contribute to a negotiated solution of Colombia's conflict and, since 11 September 2001, to adopt a tougher stance against Colombia's guerrilla and paramilitary groups (labelled as terrorist groups by the US government). American interests are reflected in the sharp increase of counter-narcotics aid and, most importantly, the Plan Colombia.

Although originally Plan Colombia was designed to be a comprehensive package comprising not only military aid but also social and economic cooperation, it has been perceived internationally as a measure principally geared at improving the Colombian army's capacity to wage war not only against drugs but also against insurgency. Human rights organizations have criticized the Colombian and the US governments for failing to show sufficient interest in ending support for paramilitary forces at all levels, and for not holding members of the Colombian security forces accountable for human rights abuses. The US Congress and the media also expressed concern regarding the regional implications of the conflict, particularly the problem of drug cultivation, money-laundering and trafficking expanding beyond Colombia's borders. In response, the Bush administration, in its first year, moved from Colombia-centred to a regional plan, dubbed the «Andean Regional Initiative» which includes Bolivia, Ecuador, Brazil, Peru, Panama and Venezuela. This plan focuses on strengthening security measures taken by neighbouring countries in border areas and provides development aid to border communities. Rejecting criticism that Plan Colombia has contributed to the worsening of the crisis, the US government has appeared more inclined to label population movements from Colombia to neighboring countries as migration rather than forced displacement. This explains why the US has channelled humanitarian funds into neighboring countries mainly through organizations such as the International Migration Organization without protection mandates.

Finally, as traditionally guerrilla controlled territories became disputed by the paramilitary groups and the army, Colombia's insurgents have over recent years trespassed the

18 JAQUemet, Stéphane. «Under What Circumstances Can a Person Who Has Taken An Active Part in The Hostilities of An International or Non-International Armed Conflict Become An Asylum-Seeker?». UNHCR Legal and Protection Policy Research Series, PPLA/2004/01, June 2004, 24.

19 CoRLISs, Steven. «Asylum state responsibility for the hostile acts of foreign exiles», 2 IfRL 181 (1990). 
country's international boundaries more and more and established a permanent presence in the border areas of neighboring countries. These are the same areas where refugee groups and individuals have been arriving. First and foremost interested in safeguarding their operations, insurgent groups have been more than interested in keeping international attention on neighboring countries' border regions low. Refugees having contact with international organizations would make the guerrillas' presence visible and risk making it a major international issue.

In the case of Venezuela, insurgent forces have furthermore considered that making the plight of refugees in border areas visible would not only undermine their own cause but also that the Chavez administration with which it has reportedly enjoyed close relations. Against this background it is not surprising that the guerrillas have pressured some refugee groups which have crossed into neighboring countries under the insurgents' auspices not to apply the international protection, while discretely requesting humanitarian aid through local NGOs.

\subsection{The Response of Neighbouring Countries to Refugee Movements}

Having illustrated the key actors' interest in concealing the international dimension of the Colombian conflict, neighbouring states, with the exception of Ecuador, adopted restrictive policies when major forced population movements started at the end of the 1990's. These policies have shaped the informal rules of communication and engagement between key actors and refugees.

As the conflict expanded to Colombia's border departments in the mid-1990s the civilian population became a military target with fewer possibilities of relocating internally. Neighbouring states started preparing themselves for spill-over effects such as refugee group outflows. Venezuela, ${ }^{20}$ Brazil, ${ }^{21}$ Peru, ${ }^{22}$ Panama $^{23}$ and Ecuador ${ }^{24}$ militarized their borders and established strict control over admission to their territory. In Venezuela and Ecuador, this control was complemented by contingency planning.

20 Theatres of Operations - large operational centres to supervise various military bases in the area - were established in the borders states of Apure (TO1, 1995) and Tachira (TO2, 1997), with some 20000 soldiers stationed in 104 military bases and check points along the border.

21 The Brazilian Government militarized its border in 2000 through «Operação Calha Norte» deploying some 3000 soldiers in various military bases along the Colombian border.

22 The Peruvian Government decided in 1998 to militarize its 1600 kilometre border with Colombia along the Putumayo River on national security grounds. This has included the dispatch of more than 2000 soldiers to prevent spill-over effects from the Colombian conflict (incursion of guerrilla, narco-traffic) into Peru.

${ }^{23}$ The Panamanian Government has dispatched some 1000 police officers by 1997 to key border locations on the Atlantic and Pacific coasts as well as in the centre of the Province of Darién, following violent paramilitary incursions and guerrilla movements.

${ }^{24}$ The Ecuadorian government has, since 2000, increased the presence of the army from 5000 to 12000 fearing the transfer of coca transplantations from Colombia to Ecuador's border areas as well as incursions from irregular armed groups. 
Whereas in 1996 Venezuela's army elaborated an internal plan for refugee flows in which refugee groups were meant to receive humanitarian assistance for a couple of days and then returned to Colombia, Ecuador's plan was established in close cooperation with UNHCR and civil authorities and foresaw reception and protection of refugees in accordance with international law and standards.

In addition to neighboring countries' desire to prevent the conflict from becoming international, little knowledge of international refugee law and limited institutional capacity meant that neighbouring countries did not make preparations for setting up new or reinforcing existing individual refugee status determination procedures or establishing tripartite mechanism with UNHCR.

\section{Panama}

The paramilitary groups first entered the region of Uraba at the Panamanian border in 1996, provoking the first outflows of various refugees groups in September 1996 and March 1997. This amounted to some 1000 people moving to Panama's border provinces of Darién and San Blas. Panama's government was quick to declare these groups 'irregular migrants', that for security reasons, 'Panama cannot be the solution for the problems of Colombia's displaced populations' and that the forced displacement of Colombians has to be resolved by the Colombian government'. The governments of Panama and Colombia then quickly organized, without involving UNHCR or any other humanitarian organization, the forced return of refugees, some of whom were killed upon their return to Colombia. ${ }^{25}$ UNHCR addressed in 1997 a formal letter to the Panamanian government wherein the organization stressed that the forced return of refugees was inconsistent with the principle of non-refoulement enshrined in Article 33 of the 1951 Convention ${ }^{26}$ and Article 22 paragraph 8 of the American Convention on Human Rights. The organization furthermore requested access to refugees in border areas and the establishment of formal status determination procedures.

\section{Venezuela}

In May 1999 paramilitaries reached the department of North Santander bordering Venezuela and started attacking the guerrilla stronghold of Catatumbo. Various refugee groups (4 000 people) crossed into Venezuela's border area. While some refugees merely requested temporary protection and the government's help to return to another area of Colombia, the majority clearly sought asylum.

${ }_{25}$ See report of the Colombian NGO CODHES. <http://www.derechos.org/nizkor/colombia/ libros/despl/10.html >.

${ }^{26}$ See the 1999 country report of the US Committee for Refugees, <http://www.refugees. org/world/countryrpt/amer_carib/1999/panama.htm>. 
Notwithstanding, the Venezuelan army implemented its 1996 contingency plan, providing temporary humanitarian assistance and returning refugees, with the proactive involvement of Colombia's civil and military authorities, to their country of origin where some of the refugees were subsequently killed. It is noteworthy, that neither UNHCR nor any other humanitarian organizations were granted access to the refugees. The governments of Colombia and Venezuela held a bilateral meeting where they categorized all persons forcibly crossing the international boundary as «internally displaced in transit» and established and ad-hoc procedure for these population movements basically consisting of short-term humanitarian assistance and the prompt return to Colombia. ${ }^{27}$ Like in the case of Panama, for UNHCR the return movement was inconsistent with international refugee law and raised important questions regarding the exercise of its supervisory role.

\section{Ecuador}

In the second half of 2000 , an armed stoppage by the guerrillas and violent clashes between insurgents and paramilitary groups over territorial control in Colombia's border department of Putumayo resulted in the outflow of an estimated $9000 \mathrm{Co}-$ lombians to Ecuador, out of which some 7000 used the Ecuadorian territory for transit and returned to another border department in Colombia. By contrast to the restrictive policies applied by the governments of Venezuela and Panama, the Ecuadorian government recognized the remaining refugees prima facie under the Cartagena Declaration. UNHCR was granted access to all refugees and registered and assisted them together with the Ecuadorian authorities.

\section{Brazil and Peru}

Colombia's departments bordering Brazil and Peru are jungle areas with no roads and are scarcely populated by the indigenous communities. While the guerrilla have used these areas for rest, recreation, training and preparing for operations against the army, the army and paramilitaries groups have not disputed the guerrillas' territorial control. Indigenous communities, some of which have been forced to provide supplies to the guerrillas and labour for the cultivation of coca, have thus been spared from massacres. Nonetheless, it cannot be denied that individuals and smaller groups have been reportedly displaced into the remote areas of Peru and Brazil, fleeing forced recruitment and other forms of persecution by the guerrillas.

To summarize, once cross-border movements of refugee groups started in. 1996, Ecuador adopted a liberal stance towards forced population movements to its territories. It acknowledged that refugees from Colombia were fleeing violations to human

${ }^{27}$ See the joint report of Venezuelan and Colombian NGOs on $<$ http://ww.derechos.org/ nizkor/venezuela/doc/refu.html>. 
rights and humanitarian law and it guaranteed their admission and protection in accordance with the 1951 Convention, the 1984 Cartagena Declaration and the 1969 American Convention on Human Rights. In contrast, the governments of other neighboring countries such as Venezuela and Panama disregarded the above international instruments. They heavily militarized their borders, applied non-admission and deportation policies in cooperation with the Colombian government and used terminology which suggested the non-international character of displacement.

\subsection{International Image Concerns and Modified Deterrent Measures}

In reaction to strong international criticism over Venezuela's and Panama's initial reaction to cross-border refugee flows, the governments of neighboring countries strove to reconcile concern over its international image with the national interest of preventing the Colombian conflict from spreading to their territories and keeping. refugee movements invisible.

At the end of the 1990s, Brazil, Panama, Venezuela and Peru started to adopt refugee legislation in coordination with UNHCR, in what has been welcomed by UNHCR and NGOs as progress towards providing effective protection to refugees in the Andean region. It is noteworthy that while in principle these laws enshrired relatively fair eligibility procedures for individual cases, they did not establish a detailed protection framework to deal with the specific cross-border displacement situations at the border. Instead, they set up temporary protection regimes that fall short of international standards in terms of duration ${ }^{28}$ and scope ${ }^{29}$ of protection. These regimes lack important refugee rights such as the right to access fair and efficient refugee status determination procedures.

While the governments of Panama and Venezuela presented national refugee legislation to the international community as evidence of their compliance with international obligations, in practice they refrained from applying the laws; denying that refugees were crossing into their territories. With migration law and security concepts of the armed forces remaining indiscriminately in force, border officials have not assumed any protection functions with regard to Colombians in need of international protection. People crossing the borders have been labelled as irregular migrants, guerrillas or criminals and have been detained and deported.

28 Panama's refugee decree $n .^{\circ} 23 / 1998$ stipulates that the duration of the temporary humanitarian status shall be only 2 months (once renewable); Venezuela's Decree $n .^{\circ} 2491 / 03$ and Peru's refugee law $n .{ }^{\circ} 27.891$ (in conjunction with its decree $n .^{\circ} 119-2003 \mathrm{RE}$ ) provide that the duration of temporary protection shall be a mere 3 months (once renewable).

29 Refugees with humanitarian/protection status enjoy virtually no rights apart from the right to return. Panama's refugee decree is the most restrictive among the three legislations as it foresees that UNHCR's access to refugees may be restricted and refugees may be returned to their country of origin based on bilateral agreements between Panama and the authorities of the country of origin. For further details see $<$ http://www.acnur.org/biblioteca/pdf/0069.pdf $>$. 
Official statistics reflect the reality that only a minor percentage of the overall refugee caseload has managed to access eligibility procedures: between 1 January 2000 and 30 June 2004, officially Panama received 2500 asylum-seekers from Colombia, Venezuela 2300 and Peru 200. By contrast, Ecuador's liberal asylum-policy has meant that in the same period some 27000 asylum-seekers were registered.

A second strategy related to international image has been to invite UNHCR to bilateral meetings dealing with cross-border movements that have been held between Colombia on the one hand, and Ecuador and Panama on the other. While tripartite meetings between Colombia, Ecuador and UNHCR have been successful in elaborating joint policies for cross-border displacement that are consistent with international standards, meetings with Panama were less productive, as the Panamanian government insisted in 'prompt return' of the refugee population as the only durable solution.

Strained relations with Colombia and the political turmoil in Venezuela have meant that no tripartite mechanisms have been set up between these two countries. In 2001, Colombia signed a bilateral agreement with Peru on cross-border displacement of Colombian refugee groups which advocates humanitarian assistance only for a short time followed by prompt «voluntary» repatriation as the only durable solution. Equally, new contingency plans in Venezuela and Panama have avoided dealing with the international protection needs of refugees.

214 It is interesting to note that even Ecuador's initially liberal approach has become more restrictive as greater numbers of refugees have appeared and applied for international protection. In 2002, Ecuador stopped recognizing refugee groups prima facie under the Cartagena Declaration, Furthermore, the eligibility commission no longer uses the Declaration's extended refugee definition for individual refugee status determination. Moreover, a growing number of asylum-applications are rejected on restrictive eligibility grounds or by applying exclusion clauses.

Finally, the Andean region's restrictive approach to refugee protection can be seen by the fact that Colombia, which hosted the conference which led to the 1984 Cartagena Declaration and its extended refugee definition, eliminated this definition from its national legislation in 2002. This action reinforced the erroneous impression that there are no refugees in the Andean region and therefore there is no need for a wider refugee regime.

\subsection{Refugees' Invisible Copying Mechanisms}

In accordance with the theory of constructivism, the informal terms of communication between governments of neighboring countries and Colombians in need of international protection were set when the first group outflows occurred, between 1996 and 1998. Militarization of the border, non-admission policies and deportation procedures carried out by neighbouring countries together with the Colombian government made clear to refugees that any attempt to cross the boundary officially and apply for 
asylum, would be met with detention or deportation. Given the lack of relocation alternatives within Colombia, refugees had to identify alternative mechanisms to ensure admission to neighboring countries' territories and obtain some sort of protection.

Different social and ethnic groups in need of international protection have coped with their protection needs in different ways:

\section{Indigenous Populations}

The worsening of Colombia's conflict meant that indigenous populations living in the remote areas in all of Colombia's border departments became a target of Colombia's irregular groups. Since the late 1990s, thousands of them have crossed into Venezuela, Panama, Peru and Ecuador, fleeing individual persecution or territorial cleansing, to join their tribes on the other side of the border. As there are no state authorities or humanitarian organizations in these remote jungle areas and outside contact has been limited, these refugees have not filed any official asylum-applications and do not appear in official statistics.

\section{Rural Refugees}

The vast majority of Colombians in need of protection in border areas has been people of mestizo or African descent from rural areas, mostly women and children, fleeing death threats, targeted persecution and/or indiscriminate massacres by guerrilla groups or paramilitaries. When these refugees first crossed in large groups into neighboring countries between 1996 and 1999 they faced non-admission and deportation. They learned that attempts to find refuge in neighboring countries have to be discreet and anonymous, on an individual or family basis instead of large group which attract the attention of border officials and central authorities.

Many refugees have crossed into remote border areas which lack basic infrastructure and authorities. The cross-border displacement of some smaller groups has taken place under the auspices of the guerrillas. The proximity to the Colombian border has allowed some to continue working during the day on Colombian territory, while spending the night across the border in neighboring countries. Contacts with military and civil authorities further inland are avoided as these contacts, including applications for asylum, bear the risk of deportation on grounds of irregular entry. Occasionally, assistance has been sought from national and international humanitarian agencies.

Other rural refugees who have managed to cross irregularly into neighboring states have found informal routes into the slums of urban centers, both along the border and further inland. They have kept silent over the reasons for their flight and avoided any contact with state authorities. As they do not possess adequate documentation, they are under permanent risk of being returned to Colombia, except for those who can afford to purchase neighboring countries' identity cards on the black market. 
The rapid growth of local slums at the borders since 1997 is an indication of the size of this movement. It is unrealistic to consider that this growth is the result of economic migration, considering the present hostile political and economic conditions in particular in Venezuela and Ecuador today; here there are few incentives for improving one's economic situation. A conservative estimate of this group is that 100000 refugees have fled to Colombia's neighboring countries since the mid-1990s. ${ }^{30}$

Ecuador's experience is an indicator of the scale of the problem: given the country's humanitarian policies towards refugees between mid-2000 and the end of 2002 some 20000 refugees have officially entered the country out of which more then 10000 applied for refugee status. Despite being able to apply for asylum in Ecuador officially, it is safe to assume that an even larger number of people have opted not to apply and to hide as irregular or regular migrants further inland, fearing that official registration with authorities would allow Colombia's irregular groups to trace them.

\section{Urban Middle Class Refugees}

A third group of refugees stem from urban areas. These are mostly educated people belonging to Colombia's middle-class. They usually have a more stable economic background and arrive on an individual basis, often via air. Most of the people have experienced individual persecution by one of Colombia's armed groups. The experience of Costa Rica, which is situated north of Panama, and thus not neighboring Colombia, gives an indication of the size of this group.

Until 16 April 2002, Costa Rica had no visa requirements for Colombians. Between mid-2000 and April 2002 more than 8000 Colombian arrived and applied for refugee status. The vast majority of Colombian asylum-seekers were professionals (lawyers, teachers, medical doctors) from urban areas with some formal education. The overwhelming majority entered Costa Rica legally by air, with valid passports. When the government eventually adopted visa requirements, the number of asylum-seekers dropped dramatically.

\subsection{The Protection and Assistance Needs of Refugees}

A fundamental question arises, given Colombian refugees' copying strategies, as to whether any international intervention is required. For a number of reasons, Colombia's invisible refugees in neighboring countries are in need of international protection.

First, the invisibility has not protected them effectively against forced return by state authorities to Colombia and, thus, to the persecutors they have been fleeing from. In Venezuela and Panama, thousands of undocumented Colombians are deported without

30 See, inter alia, the «World Refugee Survey 2002» in which the US Committee for Refugees estimates that only in Ecuador and Venezuela 100000 to 125000 Colombians have been living in refugee like circumstances. 
any procedural guarantees every month, particularly without any assessment as to whether their life or liberty is at risk upon return to Colombia. This has conflicted with Article 22 paragraph 9 of the American Convention on Human Rights and the standards of due process in deportation procedures, such as those defined by the InterAmerican Court on Human Rights. This practice has also been inconsistent with Article 31 of the 1951 Convention which provides that Contracting States shall not impose penalties, on account of their illegal entry or presence, on refugees.

The lack of documentation resulting in refugees not being able to exercise their political, civil, social, economic and cultural rights is a second reason. Even though the American Convention on Human Rights provides in Article 1 that state parties undertake to ensure to all persons subject to their jurisdiction the full exercise of its rights and freedoms, without any discrimination for reasons of "political or other opinion, national or social origin or any other social condition', there are practical difficulties for any undocumented refugee seeking to benefit therefrom. Access to public services such as education and health has been hampered for those with irregular migration status. As refugees do not possess proper documentation and permits, they have also been prevented from finding regular employment and have had to seek employment in the informal economy or in illegal activities, such as supplying guerrilla groups or cultivating and trafficking drugs. ${ }^{31}$

Third, refugees of all groups have become increasingly vulnerable - regardless of their migration status - to persecution by the paramilitary and guerrilla groups from Colombia that have been operating in the territories of neighboring states. These guerrilla groups have proved their ability to trace individuals wherever they are. In addition, irregular armed groups have been constituted in Venezuela and Ecuador which have started to target Colombians in need of international protection. An indicator of this development may be the murder rate of Colombians in the border regions of Ecuador and Venezuela which has risen dramatically over the past four years.

Finally, the restrictive asylum and migration policies of neighboring countries have proven inadequate to prevent Colombia's conflict from spilling over: paramilitary and guerrilla groups have significantly stepped up their operations in all neighboring countries, coca cultivation and drug processing operations have been transferred and refugee flows significantly augmented.

The international silence over these phenomena has largely contributed to making things worse. Acknowledging the presence of large refugee groups, as well as registering and documenting asylum-seekers, would allow neighboring states to reduce irregular border

31 The border provinces/states in Ecuador, Venezuela and Panama are among the most impoverished. Refugees compete with local populations for the already scant resources of the communities. Social services such as health, sanitation and education are usually overstretched. Because of their marginalization refugees are often exploited on the labour market. 
crossing, and thus carry out considerably more efficient control over their territories and diminish other spill-over effects such as the border crossing of the non-civilian population.

\section{Constraints of Humanitarian Agencies in Accessing and Protecting Refugees}

For various reasons, international and national humanitarian organizations have had serious difficulties in meeting the protection and assistance needs of Colombian refugees in neighboring countries.

\section{Colombia Focus}

Taking account of the interests of key actors, the international community has shown considerably more interest in the resolution of the Colombian conflict and the provision of humanitarian assistance to internally displaced populations within Colombia. One major reason for this is that despite key actors within the Colombian society downplaying the humanitarian consequences of the Colombian conflicts particularly regarding internal displacement, international consensus puts the number of IDPs at well beyond the one million threshold. ${ }^{32}$ As a result international humanitarian action has had to be taken.

As major donor countries have earmarked the bulk of funding to the Colombian crisis, the operations of under-funded UN agencies and non-governmental organizations in neighboring countries have been limited to smaller general programs in the capitals and have not encompassed refugee related activities at the border. Generally, the non-governmental organizations in neighboring countries have been unfamiliar with refugee protection requirements and suffer from weak institutional capacities. By contrast, international organizations and NGOs in Colombia have been considerably stronger and better funded.

It is interesting to note that since the end of the 1990s some NGOs in Colombia have started showing interest in the topic of refugee protection in Colombia's neighboring countries. As their focus, however, has been limited to viewing refugee movements as one of several consequences of internal displacement, their reports have not reflected the genuine dimension of external displacement and have to a certain extent contributed to the distortion of the objective reality.

32 See inter alia the Latin American Report N. ${ }^{\circ} 1$ of the International Crisis Group on «Colombia's Elusive Quest for Peace», 26 Mar. 2002, where in the highlights that «in 2000, the Representative of the UN Secretary General on internally displaced persons, Francis Deng, catalogued the situation of such individuals in Colombia as among the gravest in the world» and that «there are over a million internally displaced persons in the country with new displacements continuing to occur». 


\section{Humanitarian Organizations Hindered}

UNHCR and its NGO partners have experienced serious difficulties in effectively addressing national security and political interests in neighboring countries, especially in Venezuela and Panama. In these countries, UNHCR has been accused of 'making up the presence of refugees for justifying its presence'.

Venezuela, Panama and Brazil have shown little interest in facilitating UNHCR's access to remote border areas where refugees have fled, ${ }^{33}$ either questioning the need «as there is no forced cross-border displacement» or referring to precarious security conditions at the border. Given that all three states are parties to the international refugee instruments, there is an apparent failure to comply with Article 35 of the 1951 Convention and Article II of the 1967 Protocol. Various EXCOM conclusions have reaffirmed UNHCR's role to have prompt and unhindered access to asylumseekers, refugees and returnees. ${ }^{34}$ The regional experts meeting held in San José (Costa Rica) in June 2001, in the framework of the Global Consultations on International Protection, stressed that UNHCR has a unique responsibility with regard to supervision and this responsibility should be recognised, maintained and reinforced by States..$^{35}$

In sum, traditional capacity building activities such as training and legal advice have not managed to change states' constructed reality that no refugees except economic migrants are crossing into their territories nor change their restrictive asylum-policies.

\section{Access to Refugees Difficult}

Access to refugees has been extremely difficult. Those refugees who contacted humanitarian agencies for protection and assistance received, in some cases, very limited assistance and the pledge that their protection needs would be discussed with the government. Not only did the governments of Venezuela and Panama fail to take appropriate action but refugees were also subject to deportation and other deterrent measures. Confidence in the effectiveness of UNHCR and other humanitarian organizations has been reduced, and the benefits of officially applying for refugee status perceived as lagging way behind the costs. Additionally, in some cases insurgent groups discouraged refugees from contacting humanitarian organizations out of fear that access by agencies would jeopardize their operations in the border areas of neighboring countries.

33 Nor have they been willing to implement refugee laws at the border, give up their non-admission policies, and set up fair and efficient refugee status determination procedures.

34 Executive Committee Conclusions Nos. 22 (XXXII), 1981, para. III; 33 (XXXV), 1984, para. h; 72 (XLIV), 1993, para. b; 73 (XLV), 1994, para. b(iii); 77 (XLVI), 1995, para. q; 79 (XLVII), 1996 , para. p.

35 Global Consultations on International Protection, San José Regional Experts Meeting, 7-8 June 2001, para. XxVII, www.unhcr.ch. 


\section{No Protection Regime in Place}

With all neighboring countries refuting the applicability of the wider refugee definition of the 1984 Cartagena Declaration and the great variety of displacement situations in the border areas the different profiles and needs of refugees have not been adequately addressed. In particular, the absence of a complementary protection regime for border areas has meant that refugee laws remained inapplicable. Instead military concepts are applied, which focus on non-admission and prompt return to Colombia.

\section{The Role of UNHCR and other Organizations}

In response to the numerous challenges confronting refugee protection for states, as well as for UNHCR, and on the occasion of the $50^{\text {th }}$ anniversary of the 1951 Convention relating to the status of refugees, UNHCR set in train, in December 2000, the Global Consultations on International Protection. The purpose was to provoke both reflection and action to revitalize the 1951 Convention framework and to equip states to better address the challenges in a spirit of dialogue and cooperation. The Agenda for Protection which was adopted by UNHCR's Executive Committee in October 2002 has been a product of this consultative process.

The Agenda focuses on suggested activities which would strengthen international protection of asylum-seekers and refugees and improve implementation of the 1951 Convention and its 1967 Protocol. The document highlights the fact that refugee protection would also be enhanced by accession to, and effective implementation of, regional refugee instruments, as well as key human rights instruments. Among other activities, the Agenda outlines:

- Goal 1 (Strengthening implementation of the 1951 Convention and 1967 Protocol) - the «provision of complementary forms of protection to those who might not fall within the scope of the 1951 Convention, but require international protection»;

- Goal 2 (Protecting refugees within broader migration movements) - the «better identification of and proper response to the needs of asylum-seekers and refugees, including access to protection within the broader context of migration management» and «more effective cooperation to strengthen protection capacities in refugee-receiving countries»;

- Goal 4 (Addressing security-related concerns more effectively) - «the resourcing of states for securing the safety of refugees and for the separation of armed elements from refugee populations»;

- Goal 5 (Redoubling the search for durable solutions) - 'the realization of comprehensive durable solutions strategies, especially for protracted refugee situations'. 


\section{Refugee Visibility}

As long as the perception prevails that Colombia's conflict has produced mostly internal displacement and that external displacement to neighboring countries has been limited to the few individual cases that appear in official statistics, governments of neighboring countries, major donors and the UN system will not acknowledge the need for a stronger humanitarian response. Hence the importance of tackling the reality constructed by the key actors in the region and bringing the international dimension of refugee flows to the light.

To this end, in September 2002, UNHCR adopted the 'International Protection Considerations Regarding Colombian Asylum-seekers and Refugees'36 which are intended to inform countries of asylum and NGO partners and facilitate the adjudication of Colombian asylum applications. The document provides information on the political context of the conflict in Colombia and the security and human rights situation. It highlights the fact that many Colombians who flee across international borders have a well-founded fear of persecution for reasons set out in Article $1 \mathrm{~A}(2)$ of the 1951 Convention and the 1967 Protocol relating to the Status of Refugees. The paper adds that large numbers of Colombians require international protection because their lives, safety or freedom have been threatened by generalized violence or other circumstances which have seriously disturbed public order. The Protection Considerations describe profiles of groups of Colombians who could face a risk of persecution on the grounds described in the 1951 Convention. ${ }^{37}$ Furthermore, UNHCR calls upon states to provide subsidiary forms of protection to those cases where refugee status under the international refugee instruments is denied, yet where persons may, nevertheless, still be in need of international protection. The document suggests that regional refugee instruments such as the 1984 Cartagena Declaration of Refugees may be a suitable framework for protecting this 'broader' category of refugees. Finally, the Protection Considerations provide guidance on how the exclusion clauses of Article $1 \mathrm{~F}$ of the 1951 Convention shall be applied in the context of Colombia.

As the «international protection considerations» focus mainly on those Colombians in need of international protection who have filed asylum applications and thus appear in official statistics, it has veen necessary to complement the guidelines and assess the protection needs of those Colombian refugees in neighboring countries who have not applied for refugee status. In 2002, a regional survey was launched that aimed to measure the scope of forced displacement from Colombia to the border areas of Ecuador, Venezuela and Panama that neighboring countries and the international community have labelled as 'traditional migration movements' and specify the

${ }^{36} 15$ IFRL 318-344 (2003).

${ }^{37}$ Actual or perceived supporters of parties to the conflict, former members of parties to the conflict, municipal and departmental authorities, persons involved in the administration of justice, human rights activists, trade union leaders, individuals with a high public/community profile, journalists, indigenous persons and Afro-Colombians, and marginalized social groups. 
profile of individuals in need of international protection. ${ }^{38}$ Preliminary results ${ }^{39}$ suggest that there are some 190000 Colombians in need of international protection in the border areas of the three countries. Adding to this number the refugee populations in the capitals of the three countries, one may estimate that the total number of Colombians who have fled to the three neighboring countries in the last five to seven years ranges between 300000 to over a million. The survey substantially contributes to raising awareness of the objective reality of forced cross-border displacement in the Andean region and eases the access of Colombian refugees to international protection and durable solutions.

The rising international awareness of the magnitude of external displacement has been reflected by the recent position of the United Nations Emergency Relief Coordinator. During a visit to Colombia in May 2004, he underlined the urgency of addressing the humanitarian needs of Colombians in neighboring countries and suggested that 'a regional humanitarian conference could be the way forward'.

\section{Enhanced Operational Capability}

Given the unwillingness of the governments of Venezuela and Panama to implement refugee laws, UNHCR has started to step up its operational capacity and that of its non-governmental partners, in relation to the protection network along the border. The establishment of offices and antennae in border areas in Ecuador, Venezuela and Panama has enabled UNHCR and NGOs to improve access to people in need of international protection.

Monitoring activities, referral of asylum-applications to host governments and contacts with local authorities have been complemented by country-wide electronic registration systems ${ }^{40}$ run by UNHCR and NGOs, a systematic pre-status determination

${ }^{38}$ For further details see Fundación para la paz y la democracia (FuNPADEM). «Proyecto El desplazamiento forzado de colombianos hacia Ecuador, Panamá y Venezuela: un modelo para su descripción y diagnóstico», <http://www.funpadem.com/doc/elrostro.pdf>.

${ }^{39}$ Fundación para la paz y la democracia (FUNPADEM). "Diagnóstico de la dimensión y problemática que afecta a los desplazados hacia Ecuador, Venezuela y Panamá, por el conflicto bélico en Colombia», 2003; the report indicates that 73 per cent of this caseload is in Venezuela, 21 per cent in Ecuador and 6 per cent in Panama. The final report is likely to be presented at the occasion of the celebration of the $20^{\text {th }}$ anniversary of the Cartagena Declaration on Refugees in Mexico in November 2004 and various forthcoming conferences related to the humanitarian crisis in Colombia.

40 In Ecuador and Venezuela systems have been set up in the framework of which asylumseekers at the border are registered by the government, UNHCR or NGOs via internet directly into a central server. The database contains all relevant data of the individual cases, including pre-eligibility interviews carried out upon registration, fully-fledged eligibility interviews held by the Eligibility Commission, information related to the socio-economic situation of the asylum-seeker and the decision made by the Eligibility Commission. A database operator, located within the national eligibility commission, attributes user-names and passwords to relevant government actors, NGOs and UNHCR. Each of the different users has access only to certain parts of the electronic individual files, so that confidentiality principles are safeguarded. 
with special focus on separating genuine refugees from undeserving cases, the evaluation of assistance needs, the issuing of protection letters to asylum-seekers and the systematic relocation of threatened asylum-seekers to safer areas. These activities have been going hand in hand with efforts to improve the implementation of refugee laws and thus the response of governments.

\section{Specific Regional Protection Regime for Border Areas}

While one major reason for neighboring countries' unwillingness to acknowledge refugee movements has been the fear that Colombia's conflict might become international, another reason has been that the armed forces have perceived international and national refugee law as weakening national security strategies at the border.

As discussed, national laws have not afforded sufficient provision for displacement situations at the border nor have governments acknowledged in practice the relevance of the 1984 Cartagena Declaration in the Andean context. The $20^{\text {th }}$ anniversary of the Cartagena Declaration is an opportunity to revitalize the declaration, based on jointly agreed specific guidelines for its application. As part of the activities to mark the anniversary UNHCR is organising sub-regional meetings with governments in Central America, MERCOSUR and the Andean region. The aim is to encourage discussion among governments on the interpretation and application of the regional refugee protection instrument, particularly concerning current refugee challenges facing the Americas.

The Cartagena Declaration may be a useful basis for elaborating together with the governments of Colombia and neighbouring countries a specific regional protection regime for border areas. This regime should aim to reconcile national security interests with fundamental protection principles and complement existing refugee laws and refugee status determination procedures. It has first to tailor the Declaration's 'extended' refugee definition to the Colombian conflict. This should be done by distinguishing the different cross-border displacement situations in the Andean region, that is: refugees using neighboring countries' territories merely for transit; groups and individuals who do not want to apply for refugee status, but simply request temporary international protection for a short period of time; and groups and individuals who wish to apply for refugee status. The regime then has to define, in accordance with international refugee and human rights law, the rights applicable to each group. In particular, freedom of movement, provision of security, access to basic services and employment, documentation and access to asylum-procedures are rights that need to be further specified. Finally, specific guidelines should be elaborated for separating armed elements from civilian refugee populations and excluding undeserving cases $^{41}$ under Article $1 \mathrm{~F}$ of the 1951 Convention.

41 Larger parts of Colombia's rural populations are employed in the drug business in Colombia. This has raised complex questions as to whether their offences reach the seriousness threshold of article $1 \mathrm{~F}(\mathrm{~b})$ of the 1951 Convention once they seek international protection in neighboring countries. Moreover, there is a growing number of cases of former fighters and 
A major regional humanitarian conference following the example of the 1984 Colloquium in Cartagena and the 1989 International Conference on Central American Refugees could be a suitable forum for defining the scope of the refugee problem in the Andean region and elaborating a regional protection regime. The meeting could also be an opportunity to adopt an action plan on how to address the appalling humanitarian situation of refugee and local populations in border areas. Finally, the conference could be a useful starting point for sensitising donor countries and increasing international cooperation.

\section{The Complementarity of the Inter-American Human Rights System}

The Regional Experts Meeting held in San José in 2001 stressed the complementary relationship of International Refugee Law and the Inter-American Human Rights System. ${ }^{42}$ The Inter-American Convention on Human Rights is a useful basis for defining human rights standards that refugee groups form Colombia should enjoy in neighboring countries in the framework of the regional protection regime. The InterAmerican Human Rights System is also the appropriate forum for enforcing these standards. An analysis of Part II of the American Convention on Human Rights reveals that the organs of the Inter-American Human Rights System dispose of a wide range of means to protect refugees. This encompasses the binding provisional/precautionary measures the Court/Commission may adopt in urgent cases and advisory opinions the Court may emit on a series of issues related to asylum.

\section{Strengthening UNHCR's Supervisory Role}

UNHCR's supervisory role enshrined in Article 35 of the 1951 Convention and Article II of the 1967 Protocol is likely to be strengthened by a greater involvement of the Inter-American Human Rights System with the protection of refugees. The above regional conference for the Andean region is an opportunity for governments and UNHCR to specify the organisation's supervisory role in the Andean region.

civilians who collaborated with irregular armed groups in Colombia with respect to whom there are reasons for considering that they bear individual responsibility in relation to war crimes under article $1 \mathrm{~F}(\mathrm{a})$.

${ }_{42}$ The experts referred among others to the Provisional Measures of the Inter-American Court on Human Rights against the Dominican Republic (18 Aug. 2000), Case of Haitians and Dominicans of Haitian origin in the Dominican Republic, and the Provisional Measures of the Inter-American Court on Human Rights against Colombia (24 Nov. 2000), Case of the Peace Community of San Jose de Apartado. In the latter case the Court called on the Colombia State to create the conditions necessary for the return of Community members who had been forcibly displaced to other regions of the country and to prevent further individuals from being forcibly displaced from their homes. Likewise, reference was made to the Precautionary Measures the Inter-American Commission on Human Rights adopted in 2001 with regard to Colombian refugees in Venezuela. 


\section{Conclusions}

Through the 1990s, Colombia's conflict gradually expanded to cover the entire country and, from the mid-1990s, to spill increasingly over into neighboring states. Colombia's irregular groups have set up a permanent presence in border areas of neighboring countries to rest, supply, process and traffic drugs, to establish and maintain supportive links with irregular armed groups recently founded in some neighboring countries, and to carry out military operations against targets in both Colombia and neighboring countries.

Refugees have been a major outcome of these developments. While up to the mid$1990 \mathrm{~s}$, the number of refugees fleeing to neighboring countries was limited to individuals with no alternative options within Colombia, the dramatic expansion and deterioration of the conflict, particularly in Colombia's border departments, have forced and ever growing number of Colombians to cross into neighboring countries.

Estimates suggest that the number of Colombians who fled over the past five to seven years in search of international protection to border areas and urban centres in Ecuador, Panama and Venezuela may range between 300000 and 1 million. Among them have been individuals falling under the 1951 Convention, people and groups of all ethnic groups fulfilling the elements of the wider refugee definition of the 1984 Cartagena Declaration, and individuals with other protection needs.

Keen to prevent the Colombian conflict from becoming international, neighbouring countries have denied the conflict's spill-over effects, particularly the steadily growing refugee flows, and adopted deterrent measures to protect their territories, through military operations along the border, the adoption of non-admission policies against refugees and the systematic deportation of Colombians entering irregularly. Such practices breach the obligations owed by the neighboring states under the 1951 Convention and the 1967 Protocol with respect to Articles 31, 32, 33 and 35. They also infringe commitments under the 1969 American Convention on Human Rights.

Moreover, this strategy has proven inadequate: not only have Colombia's irregular groups further expanded their operations in neighboring countries, but an ever increasing number of refugees have managed to bypass border controls by hiding in remote areas or finding informal ways into society, as no fair refugee status determination exists. Only a few have managed to integrate; the vast majority living under irregular migration status in constant fear of being returned to Colombia or attacked by Colombia's irregular groups and struggling to meet essential humanitarian needs. With the exception of Ecuador, the restrictive attitude of neighboring countries has meant that most refugees have not been allowed to apply for asylum or any other international protection.

Undoubtedly, if neighboring countries and the international community acknowledged the regional impact of Colombia's conflict, the recognition of the presence and plight of refugees in neighboring countries would likely ensue. As this acknowledgement is 
unlikely to occur, UNHCR's role is to shed light on the presence and plight of Colombian refugees in the Andean region and remind neighboring countries that the key to international refugee protection is to be found in their territories. Against this background UNHCR has adopted a two-fold strategy in the Andean region.

Firstly, to tackle the artificial reality that Colombia's conflict has only produced internal displacement. This has been done by sharing with governments and NGOs international protection considerations regarding Colombian asylum seekers and refugees and by launching a survey in the border areas of Ecuador, Panama and Venezuela which aims to improve UNHCR's access to Colombians in need of international protection and identify their needs.

Secondly, to make the presence of refugees visible. The establishment of countrywide systems by UNHCR to electronically register and provisionally document Colombian asylum-seekers should achieve this.

However, once refugee flows have been made visible the fundamental question arises as to how to get governments to protect them. To this end, a specific protection regime has to be agreed with governments for the variety of cross-border displacement situations. This must reconcile national security interests with fundamental protection needs of Colombian refugees. This regime should complement and thus reinforce international and national refugee law and regional standards such as the 1984 Cartagena Declaration.

The celebration of the $20^{\text {th }}$ anniversary of the Cartagena Declaration on Refugees may be an opportunity to revitalize the declaration, agree on specific guidelines for its implementation and apply them to refugee movements from Colombia. A major regional humanitarian conference following the example of the 1984 Colloquium in Cartagena and the 1989 International Conference on Central American Refugees could be a suitable forum for defining the scope of the refugee problem, elaborating a protection regime and adopting a humanitarian action plan. 